\title{
PENGADAAN TANAH BAGI PEMBANGUNAN JALAN USAHA TANI DI DESA ADAT SAREN, KECAMATAN BEBANDEM KABUPATEN KARANGASEM
}

\author{
I Wayan Wahyu Dinata, Made Suwitra \& I Nyoman Sutama \\ Fakultas Ilmu Hukum, Universitas Warmadewa, Denpasar-Bali, Indonesia \\ wahyugeps23@gmail.com, madesuwitra27@gmail.com \& sutamanyoman62@gmail.com
}

\begin{abstract}
Abstrak
Pembangunan adalah upaya manusia untuk mengelola sumber daya untuk memenuhi kebutuhan dan meningkatkan kesejahteraan hidup manusia itu sendiri, begitupula pada sektor pertanian. Pembangunan Jalan Usaha Tani sangat dibutuhkan oleh para petani agar memudahkan petani untuk sampai ke lokasi pertanian dengan nyaman dan aman. Judul penelitian ini adalah Pengadaan Tanah Bagi Jalan Usaha Tani di Desa Adat Saren Kecamatan Bebandem Kabupaten Karangasem. Penelitian ini bertujuan untuk mendeskripsikan proses pengadaan tanah di Desa Adat Saren yang dilaksanakan untuk mempromosikan distribusi hasil pertanian, jalur transportasi masyarakat, normalisasi sungai dan upacara keagamaan. Selain itu juga akan mengkaji dan mengidentifikasi masalah yang akan dihadapi saat pelaksanaan pengadaan tanah untuk pembangunan jalan niaga usaha tani di Desa Adat Saren, Kecamatan Bebandem, Kabupaten Karangasem. Metode yang dipakai dalam penulisan ini adalah metode penelitian empiris yang dilengkapi dengan pendekatan perundang-undangan serta pendekatan konseptual. Sumber data yang dipakai yakni sumber data primer (hasil wawancara) serta sumber data sekunder (bahan bacaan dari penelitian kepustakaan). Hasil penelitiannya menunjukkan bahwasanya pelaksanaan pengadaan tanah meliputi perencanaan (penentuan jalan menuju ladang), persiapan dan pelaksanaan (sosialisasi, review, persetujuan, pengukuran dan penyerahan). Kendala yang muncul dalam pelaksanaan pembebasan lahan pertanian didasarkan pada beberapa faktor, antara lain faktor internal (antara lain kepentingan pribadi dan dana pembangunan) dan faktor ekstemal (antara lain lokasi geografis dan bencana alam).
\end{abstract}

Kata kunci: Desa Adat Saren, Jalan Usaha Tani, Pembebasan Lahan.

\begin{abstract}
Development is a human effort to manage resources to meet needs and improve the welfare of human life itself, as well as in the agricultural sector. Farmers really need the construction of a farm road in order to make it easier for farmers to get to the farm location comfortably and safely. The title of this study is Land Procurement for Agricultural Roads in The Village of Adat Soren District Bebandem Karangasem Regency This study aims to describe the process of land procurement at Soren Traditional Village which is carried out to promote the distribution of agricultural products, community transportation routes, river normalization and religious ceremonies. In addition, it will also review and identify problems that will be faced during the implementation of land procurement for the construction of agricultural commercial roads in Saren Indigenous Village, Bebandem Subdistrict, Karangasem Regency. The method used in this writing is an empirical research method that is equipped with legal methods as well as conceptual methods. The data sources used are primary data sources (interview results) as well as secondary data sources (reading materials from literature research. The results showed that the implementation of land procurement includes planning (determining road to the fields), preparation and implementation (socialization, review, approval, measurement and submission. The problem that arise in the implementation of agricultural land acquisition are based on several factors, including internal factors (including personal interests and development funds) and external factors (including geographical location and natural disasters
\end{abstract}

Keywords: land acquisition.farm roads, Saren villages.

\section{PENDAHULUAN}

Pembangunan adalah upaya manusia untuk mengelola sumber daya untuk memenuhi kebutuhan dan meningkatkan kesejahteraan hidup manusia itu sendiri. Manusia mempunyai kreativitas dan cita dalam mengatur dan menggunakan sumber daya alam untuk menumbuhkan kesejahteraan keturunan sekarang dan yang akan datang. Dalam pemanfaatan sumber daya alam untuk memenuhi kebutuhan masyarakat saat ini, mereka juga memperhatikan dan mengawasi generasi yang akan datang yang memenuhi 
kebutuhan tersebut berdasarkan konsep pembangunan berkelanjutan. Tanah memegang fungsi sangat urgent dalam hidup manusia, karena kehidupan manusia sangat bergantung pada tanah. Tanah dianggap sebagai property permanen yang dapat dicadangkan untuk kesejahteraan masa depan (Sitorus \& Limbong, 2004). Pengadaan atas tanah yaitu setiap kegiatan yang memperoleh hasil bumi berupa tanah dengan memberi kompensasi terhadap orang yang menyerahkan tanah, bangunan, tumbuh-tumbuhan, dan objek yang berkaitan dengan tanah. Pengambilan tanah untuk kegiatan pembangunan ini adalah cara pemerintah untuk merebut kembali tanah rakyat untuk pembangunan. Menurut Perpres Nomor 65 Tahun 2006 mengutarakan bahwa pengadaan tanah bagi pelaksanaan pembangunan untuk kepentingan umum oleh pemerintah atau pemerintah daerah dilaksanakan dengan cara pelepasan atas hak tanah (Sutedi, 2019). Fungsi humanis hak kepemilikan tanah sebagaimana dimaksud dalam Pasal 6 UUPA mencakup banyak asas kebajikan, di antaranya kepemilikan pribadi atas tanah dijamin dalam UUPA, namun pemanfaatannya untuk kepentingan perseorangan atau golongan tidak bisa berseberangan dengan kepentingan rakyatnya. Untuk menyeimbangkan kepentingan masyarakat dan kepemilikan, bagi individu atas tanah, kemakmuran, keadilan dan kesejahteraan akan muncul.

Adapun kaitannya dengan pelaksanaan pengadaan tanah yang digagasi oleh Kepala Dusun Saren Anyar, pengadaan tanah ini bertujuan untuk pembangunan Jalan Usaha Tani demi kepentingan umum. Selain itu pula, dari segi keagamaan, adanya pengadaan tanah ini dapat pula digunakan sebagai lokasi untuk pelaksanaan upacara Manusia Yadnya yaitu upacara nganyudin (sebuah prosesi untuk melarung abu pembakaran ke wilayah yang dianggap suci).

Ada beberapa penelitian terdahulu yang relevan dengan penelitian ini, Sinilele (2017) melihat dari tinjauan yuridis terhadap pelaksanaan pengadaan tanah bagi pembangunan untuk kepentingan umum di Kota Makassar. Kemudian pada penelitian selanjutnya, peneliti melakukan evaluasi terhadap infrastruktur pedesaan jalan usaha tani yang telah dibangun, karena evaluasi merupakan salah satu proses kebijakan yang harus dilakukan (Rahmadi \& Setiawati, 2020). Selanjutnya pada penelitian Rohayani \& Jamaluddin (2020) menjelaskan bahwa ada peran kepala desa dalam pembangunan infrastruktur di desa khusunya untuk pembangunan jalan usaha tani. Pada penelitian ini peneliti memutuskan untuk meneliti pengadaan tanah bagi pembangunan jalan usaha tani di desa adat saren, kecamatan bebandem kabupaten Karangasem.

Berdasarkan penjelasan diatas, penelitian ini bertujuan untuk mendeskripsikan proses pengadaan tanah di Desa Adat Saren yang dilaksanakan untuk mempromosikan distribusi hasil pertanian, jalur transportasi masyarakat, normalisasi sungai dan upacara keagamaan. Selain itu juga akan mengkaji dan mengidentifikasi masalah yang akan dihadapi saat pelaksanaan pengadaan tanah untuk pembangunan jalan niaga usaha tani di Desa Adat Saren, Kecamatan Bebandem, Kabupaten Karangasem.

\section{METODE PENELITIAN}

Metode penelitian yang akan dipakai pada penulisan artikel ini adalah metode penelitian empiris. Menurut Ronny Hanitijo Soernitro (1990) penelitian empiris adalah penelitian mengenai hukum, yang memperoleh data dari data mentah atau data yang didapatkan langsung dari rakyat. Pendekatan yang dipakai dalam penulisan ini yakni pendekatan perundang-undangan serta pendekatan konseptual yakni dengan mengkaji praktik-praktik implementasi yang ada di bidang ini terkait dengan permasalahan tersebut di atas. Mengenai sumber dibedakan menjadi bahan hukum utama yaitu data yang diperoleh dari sumber pertama, mulai dari pemberi informasi dan penanggap langsung hingga narasumber dan instansi terkait yang bersangkutan. Tujuan bahan hukum pendukung berupa studi literasi adalah untuk memperoleh konsep yang diperoleh dengan membaca, mencatat, dan mengutip data dari buku-buku hukum, jurnal-jurnal hukum serta sumber internet yang membahas hukum yang berkaitan dengan masalah penelitian (Puryanto, et al, 2021).

Teknik pengumpulan data yang digunakan dalam penelitian ini adalah wawancara, dalam hal ini wawancara yang dilakukan yakni proses tanya jawab langsung antara pewawancara (peneliti) dengan informan dari pihak-pihak pemilik tanah di Desa Adat Saren serta prajuru adat dan dinas Saren. Data yang telah dikumpulkan kemudian dianalisis dengan menggunakan teknik interpretasi dan deskriptif kualitatif, yaitu dengan menafsirkan data kemudian menyelidiki, menemukan, menggambarkan, memaparkan, dan menjelaskan kedalam bentuk kalimat agar mempermudah menarik kesimpulan. 


\section{HASIL DAN PEMBAHASAN}

1. Pelaksanaan Pengadaan Tanah Bagi Pembangunan Jalan Usaha Tani Di Desa Adat Saren, Kecamatan Bebandem Kabupaten Karangasem

Tanah dan pembangunan adalah dua unsur yang satu dengan lainnya berkaitan, dengan perkataan lain, tidak ada pembangunan tanpa tanah (Jonker, 2009). Penguasaan dan penggunaan tanah oleh siapa pun untuk tujuan apa pun harus berdasarkan dasar hukum (dasar hak). Atas dasar hukum ini telah terjalin hubungan hukum khusus antara pemilik hak atas tanah (pemilik tanah) dan tanah yang dikuasainya. Penguasaan yudisial menetapkan kekuasaan penguasaan fisik (penggunaan tanah) atas subjek pemegang hak atas tanah (pemilik tanah) berdasarkan nama dan penggunaannya. Hak atas tanah ialah hak yang memberi pengguna atau badan hukum hak pakai terhadap tanah. Pada dasamya, tujuan memakai tanah adalah untuk memenuhi dua jenis kebutuhan, yaitu untuk diusahakan dan tempat membangun sesuatu (Hutagalung \& Gunawan, 2008).

Didalam tahapan pelaksanaan pengadaan tanah, pemerintah dapat mengadopsi dua cara untuk memperoleh hak atas tanah milik anggota masyarakat. Yakni, metode pembebasan I pelepasan lahan dan metode pencabutan hak atas tanah. Pelepasan hak atas tanah serta pencabutan hak terhadap tanah yakni 2 (dua) cara untuk memperoleh hak atas tanah, dimana masyarakatnya yang membutuhkan tanah tidak dapat memperoleh hak atas tanah. Menyerahkan hak terhadap tanah ialah memberikan ganti rugi atas dasar pertimbangan, sehingga memutus hubungan hukum antara pemegang hak atas tanah dan tanah yang dikuasainya. Dapat disimpulkan bahwa hak atas tanah dapat diserahkan secara sukarela kepada Desa Adat Saren. Berikut ini merupakan proses dan alur pengadaan tanah untuk jalan usaha tani di Desa Adat Saren, Kecamatan Bebandem Kabupaten Karangasem. Pengadaan Tanah yang dilaksanakan di lokasi Jalan Usaha Tani Desa Adat Saren dimulai dari kegiatan perencanaan, persiapan dan pelaksanaan. Adapun uraian kegiatan meliputi: Penetapan Alur Jalan Usaha Tani, Sosialisasi, Musyawarah, Persetujuan, Pengukuran, Penyerahan.

Adapun Proses Pembebasan Tanah, yaitu:

a. Sosialisasi

Sosialisasi disini sangat perlu melibatkan instansi dan lnstansi yang dimaksud ialah instansi daerah disini, Pemerintah Kabupaten Karangasem, dimana Desa Adat Saren sebagai pelaksana acara tersebut. Selama proses implementasi, pihak terkait akan melaksanakan sosialisasi terhadap rakyat yang tanahnya terdampak jalan niaga milik petani. Sosialisasi semacam ini dilakukan di setiap desa, ada pemilik tanah yang terkena dampak ruas jalan usaha tani, dan didampingi tokoh masyarakat setempat, kepala desa adat dan kantor desa. Kader desa, Badan Perwakilan Desa (BPD), Babinsa, Babinkamtibnas, panitia, serta tim pelaksana teknis. Prinsipnya, masyarakat pemilik tanah secara sukarela menyerahkan tanahnya kepada pemerintah dan memberikan ganti rugi yang sesuai. Menurut Roosadijo (1997) berpendapat bahwa pembebasan tanah atau mengambil tanah yang diperlukan oleh pemerintah dengan cara pembebasan banyak dipergunakan karena cara ini dianggap lebih cepat terlaksana

Tujuan pengadaan tanah sebagai berikut:

1. Mempromosikan distribusi produk pertanian,

2. Sebagai jalur transportasi masyarakat sekitar,

3. Standarisasi sungai,

4. Digunakan untuk upacara keagamaan di masyarakat sekitar.

Materi sosialisasi yang disajikan adalah sebagai berikut:

1. Kerangka Acuan Kerja (TOR),

2. Tanggung jawab Komite Eksekutif,

3. Manfaat

4. Partisipasi masyarakat.

Sosialisasi dilakukan dalam berbagai tahap, dan warga terdampak pembebasan lahan ikut serta dalam kegiatan sosialisasi. 


\begin{tabular}{|c|c|l|}
\hline No. & \multicolumn{1}{|c|}{ Tempat } & \multicolumn{1}{c|}{ Acara } \\
\hline $\mathbf{1}$ & Di Balai Desa Saren & $\begin{array}{l}\text { Sosialisasi dan negosiasi pembebasan } \\
\text { tanah, untuk pembangunan Jalan Usaha } \\
\text { Tani di Wilayah Desa Saren }\end{array}$ \\
\hline $\mathbf{2}$ & Balai Banjar Saren Anyar & $\begin{array}{l}\text { Sosialisasi dan negosiasi pembahasan } \\
\text { tanah, untuk pembangunan Jalan Usaha } \\
\text { Tani }\end{array}$ \\
\hline $\mathbf{3}$ & Balai Banjar Saren Anyar & $\begin{array}{l}\text { Sosialisasi dengan warga Saren Anyar } \\
\text { tentang pelepasan lahan berkaitan dengan } \\
\text { pengembangan Jalan Usaha Tani }\end{array}$ \\
\hline
\end{tabular}

\section{b. Musyawarah}

Musyawarah atau negosiasi adalah kegiatan di mana para pihak mendengar, memberikan, dan menerima pendapat, yaitu hasrat untuk mencapai kesepakatan dalam bentuk ganti rugi antara pihak yang melepaskan lahan serta oknum yang memerlukan lahan. Musyawarah dilakukan untuk mencapai mufakat dengan rakyat yang wilayahnya terdampak usaha jalan niaga tani. Pertemuan konsultasi akan dilaksanakan di setiap tempat. Kantor desa yang direncanakan. Pemilik tanah yang terdampak ruas jalan usaha tani dan dengan bantuan tokoh masyarakat setempat, kepala desa adat dan pejabat desa, aparat desa, dan Badan Perwakilan Desa (BPD) ikut serta dalam Jalan Usaha Tani, Babinsa, Bhabinkamtibmas, Panitia Pembebasan Lahan, Tim Pelaksana Teknis. Dalam sosialisasi pembebasan tanah dilakukan melalui dua cara yaitu secara pendekatan langsung kepada warga dan dengan mengundang warga bersama-sama dalam sebuah musyawarah/ rapat. Musyawarah yang telah dilaksanakan kemudian akan menghasilkan suatu hasil musyawarah berupa kesepakatan atau persetujuan.

c. Persetujuan

Persetujuan disini meliputi lokasi pembangunan, luas lahan yang dibutuhkan, panjangjalan yang akan dibangun, luas lahan yang dibutuhkan, dan kompensasi yang disepakati. Kepada para pemilik tanah dan tokoh masyarakat yang terkena dampak festival Jalan Usaha Tani, serta tokoh adat dan kantor desa, perangkat desa, kantor perwakilan desa (BPD), Babinsa, Pakistan Setelah dilaksanakannya sosialisasi dan tata cara musyawarah antara peserta tanah dan tanah, Bhabinkamtibmas, panitia pengadaan, staf teknis tim pelaksana dan pemilik tanah, telah mencapai kesepakatan atas keputusan ini, sehingga dapat segera dilakukan tahap pengukuran. Jika pemilik tanah tidak mau diberi ganti rugi, mereka bisa diberi ganti rugi dalam bentuk penyertaan modal (saham) sesuai dengan aturan yang berlaku. Tanah yang dikuasai hak ulayat diganti dengan membentuk fasilitas rakyat atau bentuk manfaat lain untuk rakyat sekitar. Dari hasil musyawarah dengan warga dicapai kesepakatan sebagai berikut:

a) Disepakati pembebasan tanah dilakukan secara suka rela,

b) Tanah yang dibutuhkan dihitung dari badan sungai selebar $6 \mathrm{~m} 2$ dan panjang mengikuti aliran sungai,

c) ldentifikasi bukti kepemilikan tanah.

\section{d. Pengukuran}

Usai acara sosialisasi, satgas melakukan survey dan inspeksi lahan untuk acara tersebut, kemudian melakukan pengukuran dan memasang tiang pancang dari jarak tertentu di lahan yang akan dilintasi jalan niaga pertanian. Pemilik lahan berpartisipasi dalam pemasangan tunggul. Pemasangan patok ini memiliki fungsi supaya mengetahui pemilik bagian-bagian lahan yang dilewati jalur niaga tani. Berikut merupakan tabel tanah milik warga yang tanahnya dibebaskan untuk menjadi Jalan Usaha Tani.

e. Penyerahan

Setelah merencanakan proses atau tahapan pembangunan jalan pertanian, penulis bisa menjelaskan jika lahan rakyat bisa dilepaskan seratus persen, jalan komersial dapat dibangun. Ini akan berlanjut segera sampai setelah konstruksi selesai, petani akan dibangun. Dalam hal ini, desa harus menjaga kontak dengan masyarakat sehingga desa berkewajiban untuk melaksanakan diskusi publik, yaitu dialog atau 
proses negosiasi antara pihak yang memiliki urusan, untuk mencapai kesepakatan pembangunan lahan. Rencana amal. Pada dasarnya dalam rangka mewujudkan kepentingan umum pemerintah (dalam hal ini pemerintah daerah) dan melepaskan hak. Untuk mendapatkan hak atas tanah, masyarakat Desa Adat Saren mencapai keadilan, kemakmuran dan kemakmuran pada tanggal 2 Februari 2012. Prinsipnya, seluruh warga masyarakat yang terdampak pembebasan lahan dan pembangunan jalan komersial bagi petani di Desa Saren mendukung pembangunan petani. jalan. Ini terlihat jelas dalam proses sosialisasi, dan tidak ada yang keberatan. Warga sudah merasakan manfaat, maksud dan tujuan pembangunan jalan pertanian.

\section{Kendala Pelaksanaan Pengadaan Tanah Untuk Pembangunan Jalan Usaha Tani}

1. Faktor Penghambat Dalam Pengadaan Tanah

Permasalahan yang masih menjanggal dan menjadi kendala pelaksanaan pembebasan lahan dalam pembangunan jalan petani di Desa Saren ini merupakan permasalahan pembebasan lahan, dan warga sekitar masih merasa resah dengan pelaksanaan pembebasan lahan. Berikut adalah faktorfaktor kendala pembebasan lahan saat membangun jalan komersial di lahan pertanian.

a. Faktor Internal

1) Adanya Kepentingan Pribadi

Kepentingan pribadi, sebagian besar pemilik tanah adalah petani dan peternak yang menggunakan tanahnya sebagai tanah subur untuk bercocok tanam seperti pudak dan untuk kandang babi dan sapi.

2) Dana Pembangunan

Seperti kita ketahui bersama, dana yang digunakan berasal dari desa, jika dana terbatas maka desa adat akan mengajukan proposal ke pemerintah daerah. Apabila dana yang disebutkan dalam proses pembayaran masih terhambat dan diperkirakan akan memakan waktu lama, maka pelaksanaan pembangunan jalan tambak dapat terhambat dan proses penyelesaiannya akan memakan waktu lebih lama.

\section{b. Faktor Eksternal}

\section{1) Letak Geografis}

Lokasi pembangunan Jalan Usaha Tani yang berada di tepian sungai lumayan sulit untuk ditempuh dikarenakan disekitar lokasi tersebut banyak ditumbuhi tanaman dan pohon besar, serta adanya bebatuan vulkanik dari letusan Gunung Agung. Disamping itu pula, letak lahan warga yang berbatasan langsung dengan Desa Ababi, serta pendataan luas lahan warga ditangani oleh masing-masing pemilik wilayah secara terpisah, sehingga pelaksanaan pendataan luas lahan warga memerlukan waktu yang berbeda.

2) Bencana Alam

Hal ini tidak menutup kemungkinan karena lokasi konstruksi terletak di tepi sungai, maka risiko bencana alam (seperti banjir bandang dan aliran lahar dari letusan gunung berapi) dapat menghambat pembangunan jalan usaha tani di daerah tersebut.

2. Upaya Penyelesaian

1) Upaya Penyelesaian Kendala Internal

Apabila ditemui kendala dalam proses pengadaan tanah dan desa merupakan pihak yang memburuhkan tanah atau tanah milik penduduk, maka desa berkewajiban untuk mencari solusi terbaik berdasarkan kesepakatan kedua belah pihak.

a. Upaya Penyelesaian Dalam Memenuhi Kepentingan Pribadi

Dengan usaha bermusyawarah dalam mencarikan solusi,dimana untuk petani pudak dibantu dalam proses pencabutan dan pemindahan tanaman, sedangkan untuk petemak babi dan sapi dimana kendala utamanya adalah tempat untuk pembuangan limbah kotoran akan clibantu dalam proses pembangunan tempat pembuangan berupa septic tank.

b. Upaya Penyelesaian Dalam Dana Pembangunan

Jika dana yang diperlukan belum memenuhi am bang batas, maka perlu diadakannya penggalian dana yang akan dilakukan oleh panitia-panitia pembangunan tanpa memberatkan masyarakat sekitar.

2) Upaya Penyelesaian Kendala Eksternal

a. Upaya Penyelesaian Terkait Letak Geografis 
Mengadakan musyawarah serta sosialisasi guna membahas terkait tara cara pelaksanaan gotong royong guna membuka akses menuju lokasi Jalan Usaha Tani, adanya sosialisasi yang dilakukan secara bertahap ini bertujuan untuk memberi informasi mengenai kondisi dan letak wilayah kepemilikan tanah secara geografis supaya tidak terjadi kesalahpahaman dengan panitia pembangunan jalan usaha tani kedepannya nanti, serta juga menghindari berbagai bentuk protes dari warga yang kurang memahami kondisi wilayah tanah yang dimilikinya.

b. Pelatihan Sigap Bencana Alam

Pelatihan sigap bencana alam yang climaksud ini yaitu merupakan sebuah aksi yang diprakarsai oleh panitia pembangunan yang bekerja sama dengan pihak desa untuk mengantisipasi danjika seandainya terjadi bencana alam maka warga setempat sudah siap untuk melakukan penanggulangan dan bekerja sama secara kooperatif dengan pihak desa demi kelancaran pembangunan jalan usaha tani di wilayah tersebut.

3. Manfaat Pengadaan Tanah Untuk Jalan Usaha Tani

a. Manfaat Bagi Petani

Adapun manfaat dari pengadaan tanah bagi pemilik lahan tersebut adalah sebagai akses distribusi untuk akses-akses pertanian.

b. Manfaat Bagi Pemilik Lahan

Adapun manfaat dari pengadaan tanah bagi masyarakat sekitar lokasi pengadaan tanah tersebut tersebut adalah selain sebagai jalur distribusi, juga bisa digunakan sebagai jalur transportasi warga.

c. Manfaat Bagi Masyarakat Umum

Adapun manfaat dari pengadaan tanah bagi masyarakat yairu selain menyediakan alur sungai dengan kapasitas mencukupi guna mencegah luapan, juga dimudahkannya akses menuju sungai untuk upacara Pitra Yadnya (dalam hal ini ritual nganyudiny.

\section{SIMPULAN DAN SARAN}

1. Simpulan

Berdasarkan penjelasan pembahasan diatas, oleh karena itu peneliti dapat menarik beberapa kesimpulan sebagai berikut:

1. Desa Adat Saren melakukan pengadaan tanah melalui cara-cara sebagai berikut:

a). Proses perencanaan (dimulai dengan proses penentuan alur jalan di lahan pertanian dan pengajuan izin dari pihak terkait)

b). Persiapan dan implementasi (termasuk sosialisasi, review, perserujuan dan proses pengukuran)

c). Prosedur pengadaan tanah di lakukan sesuai dengan UU No.2 Tahun 2012

2. Adapun masalah-masalah di dalam kegiatan pengadaan jalan usaha tani didasari oleh beberapa faktor diantaranya faktor internal yaitu kepentingan pribadi, dana pembangunan, serta faktor ekstemal yaitu letak geografis dan bencana alam.

\section{Saran}

Pada penelitian ini, peneliti memiliki beberapa saran yang diharapkan dapat membantu pihak terkait agar lebih baik kedepannya, yaitu:

1. Kedepannya, untuk setiap pelepasan hak milik lahan sukarela, masyarakat akan membantu masyarakat dalam proses dan pembiayaan hak milik lahan, sehingga dapat mempercepat serta mempermudah tata cara penyerahan hak milik lahan.

2. Ke depan, sebagai bentuk rasa terima kasih kepada warga, pihak desa akan memberikan bantuan untuk mengatasi kendala-kendala yang dihadapi dalam pelaksanaan pembebasan lahan, seperti pembongkaran dan pembongkaran tanaman, pembangunan septic tank, dan pelatihan tanggap bencana. 


\section{DAFTAR PUSTAKA}

Hutagalung, A. S., \& Gunawan, M. (2008). Kewenangan pemerintah di bidang pertanahan / Arie Sukanti Hutagalung, Markus Gunawan. Raja Grafindo Persada, Jakarta.

Jonker, S. (2009). Hukum Penanaman Modal di Indonesia. Alumni. Bandung.

Puryanto, R. B., Budiartha, I. N. P., \& Ujianti, N. M. P. (2021). Perlindungan Hukum Bagi Pekerja dengan Perjanjian Kerja Tidak Tertulis Pada Perusahaan Pemberi Kerja. Jurnal Interpretasi Hukum, Vol.2(1).

Rahmadi., \& Setiawati, B. (2020). Evaluasi Program Pembangunan Infrastruktur Pedesaan Jalan Usaha Tani Desa Kandris Kecamatan Benua Lima Kabupaten Barito Timur. JAPB, Vol.3(2).

Rohayani, E., \& Jamaludin. (2020). Peran Kepala Desa Dilihat dari Aspek Informasional dalam Pelaksanaan Pembangunan Infrastruktur Jalan Usaha Tani di Desa Bagok Kecamatan Benua Lima Kabupaten Barito Timur. JAPB, Vol.3(2).

Roosadijo, M. M. (1997). Tinjauan Pencabutan Hak-Hak Atas Tanah dan Benda-Benda Yang Ada Didalamnya. Ghalia Indonesia, Jakarta.

Soemitro, R. H. (1990). Metodologi penelitian hukum (Cet.4). Ghalia Indonesia, Jakarta.

Sinilele, A. (2017). Tinjauan Yuridis terhadap Pelaksanaan Pengadaan Tanah bagi Pembangunan untuk Kepentingan Umum di Kota Makassar. Jurnal Al-Qadau, Vol.4(1).

Sitorus, O., \& Limbong, D. (2004). Pengadaan Tanah Untuk Kepentingan Umum, Mitra Kebijakan Tanah Indonesia. Mitra Kebijakan Tanah Indonesia, Yogyakarta.

Sutedi, A. (2019). Implementasi Prinsip Kepentingan Umum di Dalam Pengadaan Tanah untuk Pembangunan. Sinar Grafika, Jakarta. 